\title{
DETERMINANTS OF INJURY INCIDENTS IN THE PRODUCTIVE AGED GROUPS IN CENTRAL SULAWESI
}

\author{
Sea Septiana, Ira Marti Ayu \\ Universitas Esa Unggul
}

\begin{abstract}
Background: Based on RISKESDAS data from 2007, 2013, and 2018, the prevalence of injuries in Indonesia had increased from 7.5\%, 8.2\%, and 9.2\% respectively. In 2018, the proportion of injuries ranked $12^{\text {th }}$ place in morbidity in Indonesia with the highest cases in Central Sulawesi Province (13.8\%). This study aimed to determine of injury incidents in the productive aged groups in Central Sulawesi.

Subjects and Method: This was a cross-sectional design conducted in Central Sulawesi from October 2019 to January 2020. A total of 1,323 reproductive-aged household members was selected by random sampling method. The dependent variable was the incident of injury. The independent variables were age, gender, level of education, employment status, and nutritional status. The data were collected from secondary data of basic health research data in 2018 with household dan individual questionnaires. Bivariate analysis was performed by chi-square method.

Results: The bivariate analysis showed that the incidence of injury among the productive aged groups increased with age $(\mathrm{OR}=1.50 ; 95 \% \mathrm{CI}=1.10$ to $2.05 ; \mathrm{p}=0.021)$, gender $(\mathrm{OR}=1.29$; $95 \% \mathrm{CI}=1.03$ to $1.62 ; \mathrm{p}=0.030)$, level of education $(\mathrm{OR}=2.01 ; 95 \% \mathrm{CI}=1.14$ to $3.56 ; \mathrm{p}=0.010)$, employment status $(\mathrm{OR}=1.86 ; 95 \% \mathrm{CI}=1.19$ to $2.90 ; \mathrm{p}=0.005)$, and nutritional status $(\mathrm{OR}=$ $0.77 ; 95 \% \mathrm{CI}=0.55$ to $1.07 ; \mathrm{p}=0.033$ ).
\end{abstract}

Conclusion: The incidence of injury among the productive aged groups increases with age, gender, level of education, employment status, and nutritional status.

Keywords: injury, incidents, determinants, productive age

\section{Correspondence:}

Sea Septiana. Universitas Esa Unggul. Jl. Arjuna Utara No. 9, Kebon Jeruk, West Jakarta, 11510. Email: imseaseptiana@gmail.com. Mobile: +628978233316

The $7^{\text {th }}$ International Conference on Public Health Solo, Indonesia, November 18-19, 2020 | 345 https://doi.org/10.26911/the7thicph.04.30 